\title{
Influence of Varieties and Integrated Nutrient Management Practices on Growth and Yield of Seed in Cowpea (Vigna unguiculata L.)
}

\author{
Seema Pardhi, R.K. Sharma, S.S. Kushwah, Roshan Gallani
}

10.18805/LR-4475

\begin{abstract}
Background: Cowpea is one of the most important leguminous vegetable crops. It has a unique ability of biological nitrogen fixation and mobilization of insoluble soil nutrient and bringing qualitative changes in soil. The basic concept of integrated nutrient management system is to maintain of plant nutrients supply to achieve a good level of crop production by optimizing the benefits from all possible sources of plant nutrients in an integrated manner, appropriate to each farming system. Considering these aspects, a field experiment was conducted to boost up productivity of cowpea seed.

Methods: A field experiment was carried out during Rabi season, 2015-16 at Research Field of the Department of Vegetable Science, College of Horticulture, Mandsaur (Madhya Pradesh). The experiment was arranged in factorial randomized block design with twenty treatment combinations comprising four cowpea varieties, viz. $V_{1}-$ Pusa Sukomal, $V_{2}-K a s h i$ Unnati, $V_{3}-K_{a s h i}$ Kanchan and $V_{4}-K_{a s h i}$ Shyamal and five integrated nutrient management (INM) practices, viz. $\mathrm{N}_{1}$-Vermicompost $2.5 \mathrm{t}+$ Rhizobium (10g/kg seeds) + PSB (10 $\mathrm{g} / \mathrm{kg}$ seeds $)+\mathrm{N}(0 \mathrm{~kg})+\mathrm{P}_{2} \mathrm{O}_{5}(90 \mathrm{~kg})+\mathrm{K}_{2} \mathrm{O}(70 \mathrm{~kg}) / \mathrm{ha} ; \mathrm{N}_{2}$-Vermicompost $2.5 \mathrm{t}+$ Rhizobium $(10 \mathrm{~g} / \mathrm{kg}$ seeds $)+\mathrm{PSB}(10 \mathrm{~g} / \mathrm{kg} \mathrm{seeds})$ $+\mathrm{N}(15 \mathrm{~kg})+\mathrm{P}_{2} \mathrm{O}_{5}(90 \mathrm{~kg})+\mathrm{K}_{2} \mathrm{O}(70 \mathrm{~kg}) / \mathrm{ha} ; \mathrm{N}_{3}$-Vermicompost $2.5 \mathrm{t}+$ Rhizobium $(10 \mathrm{~g} / \mathrm{kg}$ seeds $)+\mathrm{PSB}(10 \mathrm{~g} / \mathrm{kg} \mathrm{seeds})+\mathrm{N}(20 \mathrm{~kg})$ $+\mathrm{P}_{2} \mathrm{O}_{5}(90 \mathrm{~kg})+\mathrm{K}_{2} \mathrm{O}(70 \mathrm{~kg}) / \mathrm{ha} ; \mathrm{N}_{4}$-Vermicompost $2.5 \mathrm{t}+$ Rhizobium $(10 \mathrm{~g} / \mathrm{kg}$ of seeds $)+\mathrm{PSB}(10 \mathrm{~g} / \mathrm{kg} \mathrm{seeds})+\mathrm{N}(25 \mathrm{~kg})+\mathrm{P}_{2} \mathrm{O}_{5}(90$ $\mathrm{kg})+\mathrm{K}_{2} \mathrm{O}(70 \mathrm{~kg}) / \mathrm{ha}$ and $\mathrm{N}_{5}-$ Vermicompost $2.5 \mathrm{t}+$ Rhizobium $(10 \mathrm{~g} / \mathrm{kg}$ seeds $)+\mathrm{PSB}(10 \mathrm{~g} / \mathrm{kg} \mathrm{seeds})+\mathrm{N}(30 \mathrm{~kg})+\mathrm{P}_{2} \mathrm{O}_{5}(90 \mathrm{~kg})+\mathrm{K}_{2} \mathrm{O}$ $(70 \mathrm{~kg}) / \mathrm{ha}$.

Result: In present experiment the cowpea variety $\mathrm{V}_{1}$-Pusa Sukomal recorded superior performance for growth attributes, yield and yield attributes and quality attributes. This variety had taken minimum days to first flowering, days to $50 \%$ flowering and days to harvesting. Among the nutrient levels, application of Vermicompost $2.5 \mathrm{t}+$ Rhizobium (10 g/kg seeds) + PSB (10 g/kg seeds) + N (30 $\mathrm{kg})+\mathrm{P}_{2} \mathrm{O}_{5}(90 \mathrm{~kg})+\mathrm{K}_{2} \mathrm{O}(70 \mathrm{~kg}) / \mathrm{ha}$ resulted in the highest growth parameters, yield and yield parameters of cowpea seed.
\end{abstract}

Key words: Biofertilizer, Cowpea, Nitrogen, Seed, Variety, Vermicompost, Yield attributes.

\section{INTRODUCTION}

Cowpea (Vigna unguiculata L.) is one of the most important leguminous vegetable crops. Leguminous crops play an important role in Indian Agriculture having unique ability of biological nitrogen fixation, deep root system, mobilization of insoluble soil nutrient and bringing qualitative changes in soil. It is originated from Central Africa and mainly cultivated in Asia, Africa, Central and South America. The countries like Bangladesh, China, India and Indonesia are the major cowpea growing countries in Asia. In India it is grown in the states like Rajasthan and adjoining part of Himachal Pradesh have a good acreage (Das et al., 2011).

In India, cowpea is grown widely throughout the year for all forms- tender pods, dry seeds, fodder, green manure and cover crops both as sole and mixed crop. Cowpea fixes atmospheric $\mathrm{N}$ up to $240 \mathrm{~kg} / \mathrm{ha}$ and leaves about $60-70 \mathrm{~kg}$ residual $\mathrm{N}$ for succeeding crops. Thus, cowpea is one of the most important vegetable crops in organic farming systems as it improves soil fertility even in marginal lands through provision of ground cover, plant residue, nitrogen fixation and suppressing weed and contributes to the sustainability of cropping systems. Besides plant nutrients, the presence of enzymes and hormones in manure make
College of Horticulture, Rajmata Vijayaraje Scindia Krishi Vishwa Vidyalaya, Mandsaur- 458 002, Madhya Pradesh, India.

Corresponding Author: R.K. Sharma, College of Horticulture, Rajmata Vijayaraje Scindia Krishi Vishwa Vidyalaya, Mandsaur458 002, Madhya Pradesh, India. Email: rksharma3006@gmail.com

How to cite this article: Pardhi, S., Sharma, R.K., Kushwah, S.S. and Gallani, R. (2021). Influence of Varieties and Integrated Nutrient Management Practices on Growth and Yield of Seed in Cowpea (Vigna unguiculata L.). Legume Research. DOI: 10.18805/LR-4475.

Submitted: 08-08-2020 Accepted: 10-08-2021 Online: 27-08-2021

them essential for improvement of soil fertility and productivity. Cowpea requires good quantity of nutrients throughout the growth periods especially $P$ for better development of roots, better nodulation and $\mathrm{N}$-fixation. Moreover, in early stages, plant requires $\mathrm{N}$ for better germination, production of more branches and peduncles resulting in greater number of pods, seeds and significantly higher yields (Abayomi et al., 2008).

Nitrogen is an essential constituent of protein and chlorophyll (Meena et al., 2014) and metabolic process of 
the plant growth. In addition, $\mathrm{N}$ and $\mathrm{P}$ have a stimulating effect on root activity and rooting pattern of the crop. Available nitrogenous compound (also through a starter dose) enables seedlings to make a good start even before nitrogen fixation. Phosphorus plays an important role in the plant metabolism and is a constituent of various organic substances. Similarly, potassium has a direct and indirect impact on the plant growth. Using potassium directly causes the reduced transpiration, increasing water absorption or creating internal condition in order to endure the dryness.

Bio-fertilizer promotes fertilizer use efficiency. The seed inoculation with Rhizobium increases their number in rhizosphere and enhances microbial activities. When seed of pulses, are inoculated with phosphate solubilizing bacteria (PSB) secret acetic substance which acts as solubilizer to unsoluble soil phosphorus (Khandelwal et al., 2012). Vermicompost as an organic compost and substitute for chemical fertilizer is advised by pioneer workers of organic farming. Considering these aspects, a field experiment was conducted to find out growth and yield of seed in cowpea as influenced by varieties and nutrient levels.

\section{MATERIALS AND METHOdS}

A field experiment was conducted during Rabiseason, 201516 at Research Field of the Department of Vegetable Science, College of Horticulture, Mandsaur (Madhya Pradesh). Soil of the experimental field was light alluvial having sandy loam texture with low (192 kg/ha) nitrogen, medium (19.30 kg/ha) phosphorus, high $(694 \mathrm{~kg} / \mathrm{ha})$ available potassium, $0.46 \mathrm{dSm}^{-1}$ electrical conductivity and slightly alkaline in reaction $(\mathrm{pH} 7.5)$. The experiment was laid out in factorial randomized block design with twenty treatment combinations comprising four cowpea varieties, viz. $V_{1}$ (Pusa Sukomal), $V_{2}$ (Kashi Unnati), $V_{3}$ (Kashi Kanchan) and $V_{4}$ (Kashi Shyamal) and five integrated nutrient management (INM) practices, viz. $\mathrm{N}_{1}$-Vermicompost $2.5 \mathrm{t}+$ Rhizobium $(10 \mathrm{~g} / \mathrm{kg}$ seeds $)+$ PSB $(10 \mathrm{~g} / \mathrm{kg}$ seeds $)+$ $\mathrm{P}_{2} \mathrm{O}_{5}(90 \mathrm{~kg})+\mathrm{K}_{2} \mathrm{O}(70 \mathrm{~kg}) / \mathrm{ha} ; \mathrm{N}_{2}$-Vermicompost $2.5 \mathrm{t}+$ Rhizobium $(10 \mathrm{~g} / \mathrm{kg}$ seeds) + PSB $(10 \mathrm{~g} / \mathrm{kg}$ seeds $)+\mathrm{N}(15 \mathrm{~kg})$ $+\mathrm{P}_{2} \mathrm{O}_{5}(90 \mathrm{~kg})+\mathrm{K}_{2} \mathrm{O}(70 \mathrm{~kg}) / \mathrm{ha} ; \mathrm{N}_{3}$ - Vermicompost $2.5 \mathrm{t}+$ Rhizobium $(10 \mathrm{~g} / \mathrm{kg}$ seeds) + PSB $(10 \mathrm{~g} / \mathrm{kg}$ seeds $)+\mathrm{N}(20 \mathrm{~kg})$ $+\mathrm{P}_{2} \mathrm{O}_{5}(90 \mathrm{~kg})+\mathrm{K}_{2} \mathrm{O}(70 \mathrm{~kg}) / \mathrm{ha} ; \mathrm{N}_{4}-$ Vermicompost $2.5 \mathrm{t}+$ Rhizobium $(10 \mathrm{~g} / \mathrm{kg}$ seeds) +PSB (10g/kg seeds) + N (25 $\mathrm{kg})+\mathrm{P}_{2} \mathrm{O}_{5}(90 \mathrm{~kg})+\mathrm{K}_{2} \mathrm{O}(70 \mathrm{~kg}) / \mathrm{ha}$ and $\mathrm{N}_{5}-$ Vermicompost $2.5 \mathrm{t}+$ Rhizobium $(10 \mathrm{~g} / \mathrm{kg}$ seeds $)+$ PSB $(10 \mathrm{~g} / \mathrm{kg}$ seeds $)+$ $\mathrm{N}(30 \mathrm{~kg})+\mathrm{P}_{2} \mathrm{O}_{5}(90 \mathrm{~kg})+\mathrm{K}_{2} \mathrm{O}(70 \mathrm{~kg}) / \mathrm{ha}$.

The field was ploughed thoroughly to a fine tilth with cultivator. There after field was leveled properly with heavy wooden plank by tractor and plots were prepared. The size of plot was $2.7 \mathrm{~m} \times 2.4 \mathrm{~m}$. The calculated quantities of fertilizers were applied to the each plot with the use of nitrogen (DAP, Urea), phosphorus (DAP), potash (MOP). Half dose of nitrogen and full dose of phosphorus and potash were applied as basal dose prior to sowing of cowpea seeds, while the rest of nitrogen was given at 30 days after sowing.
Vermicompost was applied as basal at the time of sowing. PSB and 1 strain of Rhizobium phaseoli were mixed and applied through seed treatment. Other intercultural operations and crop management practices were carried out in accordance with the recommended package of practices. The pure, healthy, disease and insect free vigorous and good quality cowpea seeds were used for sowing. Seed were treated with Mancozeb $2 \mathrm{~g}+$ Carbendazim $1 \mathrm{~g}$ per $\mathrm{kg}$ seeds. Seeds were sown at a depth of $3-4 \mathrm{~cm}$ in lines at a spacing of $45 \times 15 \mathrm{~cm}$. Weeding was done thrice manually at 25, 45 and 60 days after sowing. Irrigations were applied as per the requirement of the crop. The crop was sprayed with systemic insecticide at 15 days interval to control jassids, aphids and white flies etc. The data obtained on various observations for each treatment were statically analyzed as per the standard procedure.

\section{RESULTS AND DISCUSSION}

\section{Growth parameters}

There was increase in plant height with advancement of growth period (Table 1). Among varieties, $V_{1}$ (Pusa Sukomal) recorded maximum plant height $(58.31 \mathrm{~cm})$ followed by $\mathrm{V}_{4}$ (Kashi Shyamal), $V_{2}$ (Kashi Unnati) and $V_{3}$ (Kashi Kanchan). The difference in plant height in different varieties of cowpea may be due to their genetic makeup. Bahadur et al. (2008) and Ramana et al. (2010) bean also reported significant influence of varieties on plant height. Nutrient level $\mathrm{N}_{5}$ has registered maximum plant height $(55.54 \mathrm{~cm})$ followed by $\mathrm{N}_{4}$. The minimum plant height $(47.56 \mathrm{~cm})$ was observed in case of nutrient level $\mathrm{N}_{1}$. Hasan et al. (2010) and Jadhav et al. (2011) also obtained similar results in plant height due to increasing $\mathrm{N}$ fertilizer in cowpea.

The number of leaves and leaf area per plant was influenced significantly due to different treatments of varieties and nutrient levels (Table 1). Among the varieties, maximum number of leaves per plant (38.46) and leaf area per plant $\left(2440.09 \mathrm{~cm}^{2}\right)$ was observed in variety $V_{1}$ - (Pusa Sukomal), followed by variety $\mathrm{V}_{4}$ (Kashi Shyamal) and $\mathrm{V}_{2}$ (Kashi Unnati). Minimum number of leaves per plant (31.19) and leaf area per plant $\left(2034.59 \mathrm{~cm}^{2}\right)$ was observed with variety $\mathrm{V}_{3}$ (Kashi Kanchan). The plants of various varieties responded differently to environmental factors based on their genetic makeup and their adaption capability. These findings are in agreement with the finding of Alhaji (2008) and Agbogidi and Egho (2012). Significantly highest number of leaves (38.30) and leaf area per plant $\left(2452.48 \mathrm{~cm}^{2}\right)$ were reported under nutrient level $\mathrm{N}_{5}$ followed by $\mathrm{N}_{4}$ (Table 1 ). Lower number of leaves (31.69) and leaf area per plant (1991.89 $\mathrm{cm}^{2}$ ) were reported under nutrient level $\mathrm{N}_{1}$. The additional supply of nitrogen by nitrogen fixing bacteria appeared to have increased the number of leaves and thereby, greater supply of food materials through increased photosynthesis, which ultimately gave significant increase in yield parameters (Jadhav et al., 2011). These findings are in agreement with finding of Abdelhamid et al. (2011). 
More branching (10.00) in cowpea were observed by variety $\mathrm{V}_{1}$ (Pusa Sukomal) followed by $\mathrm{V}_{4}$. Cultivar $\mathrm{V}_{3}$ (Kashi Kanchan) recorded minimum number of branches per plant (8.01). These findings corroborates with those of Imran et al. (2012) and Babaji et al. (2011). Nutrient levels had exerted significant effect on number of branches per plant during all the growth stages. Highest number of branches per plant (10.58) was observed with nutrient level $\mathrm{N}_{5}$. These findings are in agreement with Satodiya et al. (2015) and Hasan et al. (2010).

Average fresh and dry weight of plant was significantly affected with varieties and nutrient levels (Table 1). Maximum fresh weight $(117.23 \mathrm{~g})$ and dry weight of plant $(32.02 \mathrm{~g})$ was recorded in variety $V_{1}$ (Pusa Sukomal) followed by variety $\mathrm{V}_{4}$ (Kashi Shyamal). Variety $\mathrm{V}_{3}$ (Kashi Kanchan) has registered minimum fresh weight $(98.24 \mathrm{~g})$ and dry weight of plant $(26.21 \mathrm{~g})$. Higher plant height, number of leaves and number of branches might have resulted in more photosynthesis and accumulation of food material in variety $\mathrm{V}_{1}$ (Pusa Sukomal) resulting in higher fresh weight and dry weight. Similar findings have been reported by Ramana et al. (2010). Nutrient levels indicated significant effect on fresh weight and dry weight of plant. Maximum fresh weight $(118.80 \mathrm{~g})$ and dry weight of plant $(32.98 \mathrm{~g})$ was observed with nutrient level $\mathrm{N}_{5}$ at all the growth stages, followed by $\mathrm{N}_{4}, \mathrm{~N}_{3}$ and $\mathrm{N}_{2}$ in descending order. Minimum fresh weight and dry weight of plant was found under $\mathrm{N}_{1}$ at all the stages of crop growth. These results are in conformity with the findings of Kumar et al. (2009).

Table 1: Effect of varieties and nutrient levels on growth parameters of cowpea.

\begin{tabular}{|c|c|c|c|c|c|c|}
\hline Treatment & $\begin{array}{l}\text { Plant height } \\
(\mathrm{cm})\end{array}$ & $\begin{array}{c}\text { No. of } \\
\text { leaves/plant }\end{array}$ & $\begin{array}{c}\text { Number of } \\
\text { branches/plant }\end{array}$ & $\begin{array}{l}\text { Leaf area } \\
\text { per plant } \\
\left(\mathrm{cm}^{2}\right)\end{array}$ & $\begin{array}{c}\text { Fresh } \\
\text { weight of } \\
\text { plant }(g)\end{array}$ & $\begin{array}{l}\text { Dry weight } \\
\text { of plant }(\mathrm{g})\end{array}$ \\
\hline \multicolumn{7}{|l|}{ Varieties } \\
\hline $\mathrm{V}_{1}$ (Pusa Sukomal) & 58.31 & 38.46 & 10.00 & 2440.09 & 117.23 & 32.02 \\
\hline $\mathrm{V}_{2}$ (Kashi Unnati) & 46.26 & 33.38 & 8.47 & 2148.95 & 102.88 & 27.26 \\
\hline $\mathrm{V}_{3}$ (Kashi Kanchan) & 45.25 & 31.19 & 8.01 & 2034.59 & 98.24 & 26.21 \\
\hline $\mathrm{V}_{4}($ Kashi Shyamal) & 54.45 & 35.38 & 8.86 & 2277.92 & 109.18 & 29.39 \\
\hline S.Em \pm & 1.25 & 1.02 & 0.39 & 44.46 & 2.76 & 0.87 \\
\hline CD $(P<0.05)$ & 3.58 & 2.93 & 1.12 & 127.30 & 7.91 & 2.48 \\
\hline \multicolumn{7}{|l|}{ Nutrient levels } \\
\hline$N_{1}$ & 47.56 & 31.69 & 7.23 & 1991.89 & 97.10 & 24.44 \\
\hline $\mathrm{N}_{2}$ & 49.11 & 32.95 & 7.79 & 2099.71 & 100.52 & 26.96 \\
\hline $\mathrm{N}_{3}$ & 50.95 & 34.30 & 9.02 & 2249.25 & 106.57 & 28.83 \\
\hline $\mathrm{N}_{4}$ & 52.18 & 35.70 & 9.54 & 2333.62 & 111.42 & 30.40 \\
\hline $\mathrm{N}_{5}$ & 55.54 & 38.38 & 10.58 & 2452.48 & 118.80 & 32.98 \\
\hline S.Em \pm & 1.12 & 0.92 & 0.35 & 39.77 & 2.47 & 0.78 \\
\hline CD $(P<0.05)$ & 3.20 & 2.62 & 1.004 & 113.86 & 7.07 & 2.22 \\
\hline
\end{tabular}

Table 2: Effect of varieties and nutrient levels on yield attributes and yields of seed in cowpea.

\begin{tabular}{|c|c|c|c|c|c|c|}
\hline Treatment & $\begin{array}{l}\text { Number of } \\
\text { pods/plant }\end{array}$ & $\begin{array}{l}\text { Pod length } \\
\quad(\mathrm{cm})\end{array}$ & $\begin{array}{l}\text { Number of } \\
\text { seeds/pod }\end{array}$ & $\begin{array}{l}\text { Seed yield } \\
\text { (g/plant) }\end{array}$ & $\begin{array}{l}\text { Seed yield } \\
\text { (q/ha) }\end{array}$ & $\begin{array}{l}\text { Harvest } \\
\text { index }(\%)\end{array}$ \\
\hline \multicolumn{7}{|l|}{ Varieties } \\
\hline $\mathrm{V}_{1}$ (Pusa Sukomal) & 20.59 & 32.69 & 12.81 & 12.50 & 18.48 & 44.58 \\
\hline $\mathrm{V}_{2}$ (Kashi Unnati) & 17.99 & 35.39 & 10.49 & 10.53 & 15.57 & 40.77 \\
\hline $\mathrm{V}_{3}$ (Kashi Kanchan) & 15.73 & 30.21 & 10.05 & 10.25 & 15.12 & 39.22 \\
\hline $\mathrm{V}_{4}$ (Kashi Shyamal) & 18.79 & 31.81 & 11.41 & 11.09 & 16.39 & 41.67 \\
\hline S.Em \pm & 0.51 & 0.71 & 0.37 & 0.45 & 0.65 & 1.06 \\
\hline$C D(P<0.05)$ & 1.45 & 2.02 & 1.05 & 1.28 & 1.87 & 3.05 \\
\hline \multicolumn{7}{|l|}{ Nutrient levels } \\
\hline $\mathrm{N}_{1}$ & 15.93 & 30.63 & 9.23 & 9.66 & 14.31 & 39.11 \\
\hline $\mathrm{N}_{2}$ & 16.97 & 31.27 & 10.06 & 10.49 & 15.54 & 40.05 \\
\hline $\mathrm{N}_{3}$ & 18.41 & 31.94 & 11.06 & 10.98 & 16.27 & 41.57 \\
\hline $\mathrm{N}_{4}$ & 19.38 & 33.30 & 11.99 & 11.57 & 16.92 & 42.11 \\
\hline $\mathrm{N}_{5}$ & 20.69 & 35.48 & 13.62 & 12.76 & 18.90 & 44.96 \\
\hline S.Em \pm & 0.45 & 0.63 & 0.33 & 0.40 & 0.59 & 0.95 \\
\hline$C D(P<0.05)$ & 1.29 & 1.81 & 0.94 & 1.15 & 1.68 & 2.72 \\
\hline
\end{tabular}




\section{Yield parameters and yield}

Variety $\mathrm{V}_{1}$ (Pusa Sukomal) recorded maximum number of pods per plant (Table 2) i.e. 20.59 followed by varieties $\mathrm{V}_{4}$ (Kashi Shyamal) and $\mathrm{V}_{2}$ (Kashi Unnati). Minimum number of pods per plant (15.73) observed with variety $V_{3}$ (Kashi Kanchan). Similar results have been reported by Imran et al. (2012) and Kwaga (2014). Nutrient levels exhibited significant effect on number of pods per plant in cowpea. Maximum number of pods per plant (20.69) was found with application of nutrient level $\mathrm{N}_{5}$. It was followed by $\mathrm{N}_{4}, \mathrm{~N}_{3}$ and $\mathrm{N}_{2}$ in descending order. Minimum number of pods per plant (15.93) was observed with application of nutrient level $N_{1}$. This might be due to optimum supply of $\mathrm{N}$ in alleviating nutritional deficiency in plants particularly at reproductive phase which resulted in producing more number of pods per plant. These findings are in close conformity with Patel and Jadav (2010) and Khandelwal et al. (2012).

Variety $\mathrm{V}_{2}$ (Kashi Unnati) had longest pod $(35.39 \mathrm{~cm}$ ) followed by $V_{1}$ (Pusa Sukomal) and $V_{4}$ (Kashi Shyamal). Minimum pod length $(30.21 \mathrm{~cm})$ was found in case of variety $\mathrm{V}_{3}$ (Kashi Kanchan). These findings are in accordance with Babaji et al. (2011) and Imran et al. (2012). Nutrient level $\mathrm{N}_{5}$ was registered maximum value of pod length $(35.48 \mathrm{~cm})$ followed by $\mathrm{N}_{4}$. Lowest value of pod length $(30.63 \mathrm{~cm})$ was observed in case of nutrient level $N_{1}$. Nutrient level $N_{1}$ might have not provided sufficient nitrogen that reduced the pod length in cowpea. Similar results have also been reported by Satodiya et al. (2015).

Maximum value for number of seeds (12.81) per pod (Table 2) was observed with variety $V_{1}$ (Pusa Sukomal). It was followed by varieties $V_{4}$ (Kashi Shyamal) and $V_{2}$ (Kashi Unnati). Minimum value for number of seeds per pod (10.05) was recorded with variety $\mathrm{V}_{3}$ (Kashi Kanchan). The results are agreement with Imran et al. (2012) and Jakusko et al. (2013). Application of nutrient levels caused significant influence on number of seeds per pod (Table 2). Higher levels of nutrient resulted increase in number of seeds per pod. Maximum number of seeds per pod (13.62) was taken with application of nutrient level $\mathrm{N}_{5}$ which was significantly higher over other nutrient levels. It was followed by $N_{4}, N_{3}$ and $\mathrm{N}_{2}$ in descending order. Minimum number of seeds per pod (9.23) was recorded under nutrient level $N_{1}$. The increased supply of nitrogen and its higher uptake by plant might have stimulated the rate of various physiological processes in plant and led to increase growth and yield (Khandelwal et al., 2012). Similar results have been reported by Patel and Jadav (2010), Jadhav et al. (2011) and Salehin and Rahman (2012).

Among varieties, $V_{1}$ (Pusa Sukomal) was recorded maximum seed yield per plant $(12.50 \mathrm{~g})$ and seed yield per hectare $\left(18.48 \mathrm{q}\right.$ ), followed by $\mathrm{V}_{4}$ (Kashi Shyamal) and $\mathrm{V}_{2}$ (Kashi Unnati). The lowest seed yield per plant $(10.25 \mathrm{~g}$ ) and seed yield per hectare (15.12 q) were observed with variety $\mathrm{V}_{3}$ (Kashi Kanchan). These results are in agreement with the observation of Alhaji (2008). and Kwaga (2014). Nutrient levels exerted significant influence on seed yield per plant $(\mathrm{g})$ and seed yield per hectare $(\mathrm{q})$. Highest seed yield per plant $(12.76 \mathrm{~g})$ and seed yield per hectare (18.90 q) were taken under the nutrient level $\mathrm{N}_{5}$ followed by $\mathrm{N}_{4}$. Nutrient level $N_{5}$ recorded $32.07 \%$ higher yield over $N_{1}$. Minimum seed yield per plant $(9.66 \mathrm{~g})$ and seed yield per hectare (14.31 q) were observed in case of nutrient level $\mathrm{N}_{1}$. Higher photosynthetic area, more dry matter accumulation might have resulted in seed yield per plant and seed yield per hectare in variety $V_{1}$ (Pusa Sukomal). Similar results have been reported by Abayomi et al. (2008), Patel and Jadav (2010) and Jadhav et al. (2011).

Among the varieties, $V_{1}$ (Pusa Sukomal) was found maximum harvest index (44.58\%) (Table 2), followed by $V_{4}$ (Kashi Shyamal) and $\mathrm{V}_{2}$ (Kashi Unnati). Minimum harvest index $(39.22 \%)$ was recorded with variety $V_{3}$ (Kashi Kanchan). Similar results have been reported by Uma and Salimath (2006). Nutrient levels exhibited significant effect on harvest index in cowpea. Maximum harvest index $(44.96 \%)$ was found with application of nutrient level $\mathrm{N}_{5}$. Minimum harvest index $(39.11 \%)$ was observed with application of nutrient level $\mathrm{N}_{1}$. These findings are in agreement with the results obtained by Kumar et al. (2009) and Abdelhamid et al. (2011).

\section{CONCLUSION}

On the basis of present experiment, it may be concluded based on present field investigation that varieties as well as integrated nutrient management practices has significantly influenced on growth, yield and yield parameters of cowpea. Among the varieties, $V_{1}$ (Pusa Sukomal) was recorded superior performance for growth attributes, yield and yield attributes over other varietie. Among the nutrient levels $\mathrm{N}_{5}$ \{Vermicompost $2.5 \mathrm{t}+$ Rhizobium $(10 \mathrm{~g} / \mathrm{kg}$ seeds) + PSB $(10 \mathrm{~g} /$ $\mathrm{kg}$ seeds $\left.)+\mathrm{N}(30 \mathrm{~kg})+\mathrm{P}_{2} \mathrm{O}_{5}(90 \mathrm{~kg})+\mathrm{K}_{2} \mathrm{O}(70 \mathrm{~kg}) / \mathrm{ha}\right\}$ resulted in the highest growth parameters, yield and yield parameters of cowpea seed.

\section{REFERENCES}

Abayomi, Y.A., Ajibade, T.V., Sammuel, O.F. and Sa'adudeen, B.F. (2008). Growth and yield responses of cowpea [Vigna unguiculata (L.) walp] genotypes to nitrogen fertilizer (NPK) application in the Southern Guinea Savanna zone of Nigeria. Asian Journal of Plant Science. 7: 170-176.

Abdelhamid, T.M., Selim, E.M. and EL-Ghamry, A.M. (2011). Integrated effects of bio and mineral fertilizers and humic substances on growth, yield and nutrient contents fertigated cowpea (Vigna unguiculata L.) grown on sandy soils. Journal of Agronomy. 10: 34-39.

Agbogidi, O.M. and Egho, E.O. (2012). Evaluation of eight varieties of cowpea [Vigna unguiculata (L.) Walp] in Asaba agroecological environment, Delta State, Nigeria. European Journal of Sustainable Development. 1: 303-314.

Alahaji, I.H. (2008). Yield performance of some cowpea varieties under sole and intercropping with Maize at Bauchi, Nigeria. An International Multidisciplinary Journal, Ethiopia. 2: 278-291. 
Babaji, B.A., Yahaya, R.A. and Mahadi, M.A. (2011). Growth attributes and pod yield of four cowpea (Vigna unguiculata L.) varieties as influenced by residual effect of differentapplication rates of farmyard manure. Journal of Agricultural Science. 3: 165-171.

Bahadur, A., Singh, K.P., Varma, A., Rai, A.K. and Rai, M. (2008). Response of cowpea genotypes to seed inoculation of biofertilizers. Vegetable Science. 35: 62-64.

Das, B., Wagh, A.P., Dod, V.N., Nagre, P.K. and Bawkar, S.O. (2011). Effect of integrated nutrient management on cowpea. The Asian Journal of Horticulture. 6: 402-405.

Hasan, M.R., Akbar, M.A., Khandaker, Z.H. and Rahman, M.M. (2010). Effect of nitrogen fertilizer on yield contributing character, biomass yield and nutritive value of cowpea forage. Bangladesh Journal of Animal Science. 39: 83-88.

Imran, M., Qamar, I.A., Muhammad, S., Mahmood, I.A., Chathha, M.R., Gurmani, Z.A., Anjum, A.S. and Shahid, M.N. (2012). Comparison of different cowpea varieties/lines for green fodder and grain yield under rainfed conditions of Islamabad, Pakistan. Sarhad Journal of Agriculture. 28: 41-46.

Jadhav, D.K., Patel, B.N. and Kad, S.T. (2011). Influence of Rhizobium seed inoculation, nitrogen and phosphorus levels on growth, seed yield and quality of cowpea cv. Pusa Phalguni. International Journal of Forestry and Crop Improvement. 2: $114-117$.

Jakusko, B.B., Anasunda, U.I. and Mustapha, A.B. (2013). Effect of inter-row spacing on some selected cowpea [Vigna unguiculata (L.) Walp] varieties in Yola, Adamawa State, Nigeria. Journal of Agriculture and Veterinary Science. 2: 30-35.

Khandelwal, R., Choudhary, S.K., Khangarot, S.S., Jat, M.K. and Singh, P. (2012). Effect of inorganic and bio-fertilizers on productivity and nutrients uptake in cowpea [Vigna unguiculata (L.) walp]. Legume Research. 35: 235-238.
Kumar, R.P., Singh, O.N., Singh, Y., Dwivedi, S. and Singh, J.P. (2009). Effect of integrated nutrient management on growth, yield, nutrient uptake and economics of french bean (Phaseolus vulgaris). Indian Journal of Agricultural Science. 79: 122-128.

Kwaga, Y. M. (2014). Evaluation of some cowpea (Vigna unguiculata L. Walp) genotypes at Mubi, Northern Guinea Savanna of Nigeria. The International Journal of Engineering and Science. 3: 44-47.

Meena, J.S., Verma, H.P. and Picholi, P. (2014). Effect of fertility levels and biofertilizers on yield, quality and economic of cowpea. Agriculture for Sustainable Development. 2:162164.

Patel, B.N. and Jadav, D.K. (2010). Effect of Rhizobium seed inoculation, nitrogen and phosphorus on growth, nodulation, flowering and seed yield of cowpea cv. Pusa Phalguni (Vigna unguiculata Walp). International Journal of Agricultural Sciences. 6:361-364.

Ramana, V., Ramakrishna, M., Purushotham, K. and Reddy, K.B. (2010). Effect of bio-fertilizers on growth, yield attributes and yield of french bean (Phaseolus vulgaris L.). Legume Research. 33:178-183.

Salehin, F. and Rahman, S. (2012). Effects of zinc and nitrogen ertilizer and their application method on yield and yield components of Phaseolus vulgaris L. Agricultural Sciences. 3: 9-13.

Satodiya, B.N., Patel, H.C. and Soni, N.V. (2015). Effect of planting density and integrated nutrient management on flowering, growth and yield of vegetable cowpea [Vigna unguiculata (L.) Walp]. The Asian Journal of Horticulture. 10: 232-236.

Uma, M.S. and Salimath, P.M. (2006). IC 259084 - A new early maturing productive genotype of cowpea. Indian Journal of Plant Genetic Resources. 19: 272-273. 